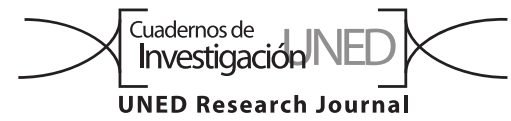

\title{
Morphometry and burst swimming in six continental fish species from Costa Rica
}

\author{
Francisco Quesada-Alvarado ${ }^{1,2} \&$ Fernando Campos-Calderón ${ }^{3}$
}

1. Universidad Nacional, Instituto Regional de Estudios en Sustancias Tóxicas, Heredia, Costa Rica; francisco.quesada.alvarado@una.ac.cr; iD https://orcid.org/0000-0001-9025-3009

2. Universidad de Costa Rica, Escuela de Biología, Programa Regional de Posgrado en Biología, Sistema de Estudios de Posgrado, San José, Costa Rica; franqal@gmail.com; (iD https://orcid.org/0000-0001-9025-3009

3. Universidad Nacional, Departamento de Física, Servicio Regional de Oceanografía (SERIO). 86-3000 Heredia, Costa Rica; fer.camp@icloud.com; (D) https://orcid.org/0000-0003-4969-4368

Received 24-IV-2019 • Corrected 09-VIII-2019 • Accepted 26-VIII-2019

DOI: https://doi.org/10.22458/urj.v11i3.2701

\begin{abstract}
Introduction: Current research of fish locomotion is focused on creating better underwater vehicles and how environmental stress factors modify swimming. Objective: To study the relation of morphometric characteristics with burst swimming in six representative species of continental fishes from Costa Rica. Methods: We measured total length, standard length, height and area of the tail of 38 individuals from six species. We used a Kruskall-Wallis test and a Boxplot graphic to compare species; and a PCA test to identify body variables that influence swimming. A Non-Metric Dimensional Scaling (NMDS) test was done for species and position in the water column. Results: The fastest swimming corresponded to A. nigrofasciata $(9,29 \mathrm{~cm} / \mathrm{s})$, while $S$. salvini $(1,65 \mathrm{~cm} / \mathrm{s})$ was the slowest. Burst swimming speed is influenced by body size and tail type, and differed with position in the water column, being surface species the fastest. Conclusions: Morphological and ecological characteristics determine differences in burst swim.
\end{abstract}

Key words: Velocity, morphometric characteristics, locomotion, ecology, riverine ecosystems, freshwater.
RESUMEN: "Morfometría y nado explosivo es seis especies de peces continentales de Costa Rica". Introducción: La investigación actual sobre del nado de los peces se centra en crear vehículos autónomos submarinos y cómo factores ambientales de estrés modifican la natación. Objetivo: Estudiar la relación de las características morfométricas con el nado explosivo para seis especies representativas de peces continentales de Costa Rica. Metodología: Medimos la longitud total, la longitud estándar, la altura y el área de la cola de 38 individuos de seis especies. Usamos la prueba de Kruskall-Wallis y un gráfico de diagrama de cajas para comparar las especies; , y un análisis de componentes principales (PCA) para identificar las variables corporales que influyen en el nado. Una prueba de escalamiento no dimensional métrico (NMDS) para mostrar la relación entre las especies y la posición ecológica en la columna de agua. Resultados: El nado más rápido se encontró en $A$. nigrofasciata $(9,29 \mathrm{~cm} / \mathrm{s})$, mientras que $S$. salvini $(1,65 \mathrm{~cm} / \mathrm{s})$ fue la especie más lenta del estudio. La velocidad de la ráfaga de natación está influenciada por el tamaño del cuerpo y el tipo de cola, y difiere por la posición en la columna de agua, siendo las especies en la superficie las más rápidas. Conclusiones: Las características morfológicas como las ecológicas determinarán las diferencias en la velocidad de nado explosivo.

Palabras clave: Nado explosivo, características morfométricas, locomoción, ecología, ecosistemas riparios, Costa Rica.
The aquatic locomotion is critical for fish survival since it affects the lifecycle of each organism (Weihs, 1973; Videler, 1993; Robolledo, Landaeta, \& Muñoz, 2014). The swimming abilities of fish species influence activities such as feeding, reproduction, escaping from predator, migration patterns and access to territory (Fausch, Torgersen, Baxter, \& Li, 2002; Faria \& Gonçalves, 2010).
There are several classifications of swim movement in fish. According to the form of locomotion, there are two main types of locomotion: (I) undulatory movement of body and caudal fin and (II) median movement of paired fins (Blake, 1983; Videler, 1993). In regards to the temporal scale: (I) periodic or sustained swim, typically used to swim long distances at a continuous speed and 
(II) transient movements, such as rapid escape manoeuvres or fast movements to catch prey (Sfakiotakis, Lane, \& Davies, 1999). Finally, there is also an order according to the performance: (I) Sustained, that is defined as filled aerobically for long times (II) Prolonged, that is defined as fully aerobically but lasts a shorter time period than the sustained and (III) Burst anaerobic swim that reaches maximum speed (Reidy, Kerr, \& Nelson, 2000; Plaut, 2001; Robolledo et al., 2014).

The fish swim process is the result of several convergent processes at anatomic, physiological and even environmental factors (Videler, 1993). The morphological characteristics; muscular structure (myotome organization) and the skin type are important adaptations of each specie (Weihs, 1973; Videler, 1993; Maddock, Bone, \& Rayner, 1994; Altringham \& Ellerby, 1999; Sfakiotakis et al., 1999; Blake, 2004; Nowroozi \& Brainerd, 2014).

The integration of how the physical environment affects the swimming biomechanics is a complex issue that incorporates ethological aspects, intra and inter specific species relations that go beyond simple body and metabolic costs (Altringham \& Ellerby, 1999; Liao, 2007; Binning, Roche, \& Layton, 2013; Marras et al., 2015). Environment forces have influenced the aquatic movement, incompressibility and high density which are key physical properties of water as a locomotion medium (Altringham \& Ellerby, 1999). Other physical variables such as levels of oxygen, temperature, acidification and pollutants can dramatically affect the capability of locomotion on fishes (Johansen \& Jones, 2011; Domenici et al., 2013; Afshan et al., 2014).

Current research of fish locomotion is focused on movements to develop autonomous underwater vehicles (Shang, Wang, Tan, \& Cheng, 2012; Flammang, Tangorra, Mignano, \& Lauder, 2017) and environmental stress factors that modify the swim (Johansen \& Jones, 2011; Binning et al., 2013; Domenici, Herbert, Lefrançois, Steffensen, \& McKenzie, 2013; Afshan et al., 2014). A significant anthropogenic stress factor is the construction of barriers such as dams and bridges (Gibson, Haedrich, \& Wernerheim, 2005; Katopodis, 2005). Usually, these human structures do not consider the capacity of fish to cross them (Gibson et al., 2005; Katopodis, 2005), which can cause habitat fragmentation and population isolation (Perkin et al., 2015). Thus, it is important to contemplate the main aspect of fish locomotion for the development and design of passage, exclusion and guidance systems. The burst swim is useful to escape from predation, feeding and cross (Reidy et al., 2000; Robolledo et al., 2014) and can be correlated with the ability to survive mortality (Nelson \& Claireaux, 2002).
Research into the impacts of river infrastructure on Costa Rica is related to other topics, such as mammals (Picado, Parallada, Mora, \& Sánchez, 2017), plants (Benavides, Barboza, Rodríguez, \& Gairaud, 2015; Campos, 2017) and habitat fragmentation (Farah, 2016). The results of this study into the morphology and ecology of a fish species in relation to the burst speed can serve as a baseline of information for the country. The objective of this study was to determine the relationship between the burst swim speed and the morphological and ecological characteristics from six representative species of riverine ecosystems in Costa Rica.

\section{MATERIALS AND METHODS}

Two field visits were made to the South Pacific and the Caribbean slope. On the Pacific; the fishes were collected from Ceibo River $\left(9^{\circ} 10^{\prime} 41^{\prime \prime} \mathrm{W}-83^{\circ} 20^{\prime} 41^{\prime \prime} \mathrm{N}\right)$, a tributary of the Grande de Térraba. On the Caribbean; in a tributary stream of the San José River $\left(83^{\circ} 52^{\prime} 58,34^{\prime \prime} \mathrm{W}\right.$ - $\left.10^{\circ} 13^{\prime} 12,54^{\prime \prime} \mathrm{N}\right)$. Additional organisms raised in the laboratory were used from the Humid Laboratory of the School of Biological Sciences of the Universidad Nacional in Heredia. Species selection was based on the number of organisms collected and that were representative and common species on both slopes (Sibaja, Bussing, GaritaAlvarado, \& López, 2013).

The different individuals used for the morphometric and swimming measurements were collected through field and laboratory visits. Adult and juvenile fishes were sampled with a Smith-Root Model LR-24 backpack electro fisher and purse seine. All the collected organisms were classified up to the species level, according to Bussing (2002) and the current taxonomic validity was verified (Eschmeyer, 2018).

Morphometric measurement: Data collected included total length (TL), standard length (ST), extended tail height $(\mathrm{H})$ according to Holden and Raitt (1974) using a Vernier calliper. For the tail area (A) measurement, each fish was photographed and we used the UTHSCSA Image Tool for Windows 3 image analysis software to determine the area of the tail of each organism tail picture.

Burst swim estimation: The burst speed was measured in a plastic channel of a meter and a half length, width of $30 \mathrm{~cm}$ and a height of $15 \mathrm{~cm}$. The channel was sealed at the ends, furthermore with a scale at the bottom and filled at $10 \mathrm{~cm}$ of water at $20^{\circ} \mathrm{C}$. After five minutes of acclimatization, the individual was subjected to a 
mechanic stimulus with the hand simulating an attack to induce the explosive swim (from the moment of start to the end of the movement). The velocity ( $v$ ) was measured with chronometer and distance displaced in straight line . Each fish was tested in three replicas, allowing the individual to rest for one minute between each replica. The speed for each individual was standardized by dividing velocity according to their standard body length.

To sort out the position in the water column (PWC) of each specie, we used the information in Chapman, Kramer and Chapman (1991), Wisenden (1994), TrujilloJiménez (1998), Tabash and Guadamuz (2000), Barboza and Villalobos (2018) and Djumanto, Ustadi, Rustadi and Triyatmo (2018).

The averages and standard deviations of all morphological measurements (TL, SL, H, A and V) were calculated for each species (Table 1). A Kruskall-Wallis test and a Boxplot graphic determined if there were significant differences between burst swim at species level. A Principal Components Analysis (PCA) was performed to determine which body variables (Total length, Standard length, Tail height and Tail area) influence explosive swimming. Additionally, a Non-Metric Dimensional Scaling (NMDS) test was performed to show the relationship between species according to the variables previously used and the position in the water column. The statistical analyses and graphing were carried out on the software Past 3 and R 3.5.1.

\section{RESULTS}

The species with the highest rate of explosive swimming was A. nigrofasciata $(9,29 \mathrm{~cm} / \mathrm{s})$, while S. salvini $(1,65 \mathrm{~cm} / \mathrm{s})$ was the species with the lowest explosive swimming speed (Table 1; Fig. 1). A significant difference was found between the values of explosive swimming among all the species used during the present study (Kruskal-Wallis, test $p<0,05, H=16,88$ ). The boxplot of burst speed $(\mathrm{cm} / \mathrm{s})$ per specie showed a well-portrayed difference (Fig. 1), A. nigrofasciata was the fastest swimmer and the specie who presented more variation.

The PCA matrix of morphological variables had two axes with an eigenvalue $>1$, which explained roughly $99,82 \%$ of the variance in the data. The PCA showed that the size of the fish and the area of the tail are the variables

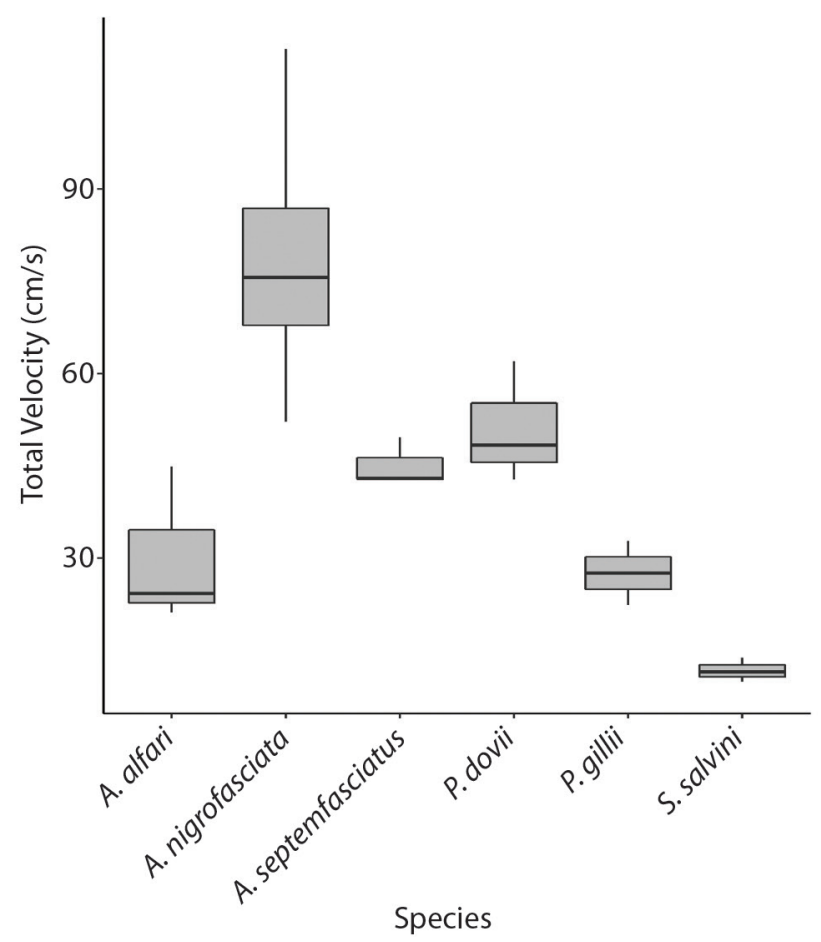

Fig. 1. Burst swim $(\mathrm{cm} / \mathrm{s})$ of six species of freshwater fish for Costa Rica.

TABLE 1

Ecological and morphological characteristics of the species used. The Position in the Water Column (PWC), Tail Type (TT), Total length $(\mathrm{TL})$, standard length $(\mathrm{SL})$, extended tail height $(\mathrm{H})$, and tail area $(\mathrm{s})$ and average Speed $(\mathrm{V})$

\begin{tabular}{|c|c|c|c|c|c|c|c|c|c|}
\hline Family & Species & $\mathrm{N}$ & PWC & TT & $\mathrm{TL}(\mathrm{cm})$ & $\mathrm{SL}(\mathrm{cm})$ & $\mathrm{H}(\mathrm{cm})$ & $\mathrm{s}\left(\mathrm{cm}^{2}\right)$ & $\mathrm{V}(\mathrm{cm} / \mathrm{s})$ \\
\hline \multirow[t]{4}{*}{ Cichlidae } & $\begin{array}{l}\text { Amphilophus alfari } \\
\text { (Meek 1907) }\end{array}$ & 6 & Medium & Truncated & $8,68 \pm 2,82$ & $6,34 \pm 2,12$ & $1,6 \pm 0,33$ & $2,14 \pm 0,8$ & $4,91 \pm 1,7$ \\
\hline & $\begin{array}{l}\text { Amatitlania nigrofasciata } \\
\text { (Günther 1867) }\end{array}$ & 8 & Medium & Convex & $14,12 \pm 3,51$ & $10,89 \pm 2,74$ & $3,37 \pm 0,17$ & $7,2 \pm 1,71$ & $9,29 \pm 2,4$ \\
\hline & $\begin{array}{l}\text { Parachromis dovii } \\
\text { (Günther 1864) }\end{array}$ & 6 & Medium & Truncated & $17,14 \pm 2,82$ & $12,95 \pm 2,11$ & $3,25 \pm 3,25$ & $8,11 \pm 2,68$ & $3,18 \pm 1,5$ \\
\hline & $\begin{array}{l}\text { Cryptoheros septemfasciatus } \\
\text { (Regan 1908) }\end{array}$ & 6 & Medium & Convex & $21.5 \pm 5.09$ & $17,29 \pm 4,51$ & $6,34 \pm 2$ & $15,34 \pm 6,93$ & $4,10 \pm 0,19$ \\
\hline Gobiidae & $\begin{array}{l}\text { Sicydium salvini } \\
\text { (Ogilvie-Grant 1884) }\end{array}$ & 6 & Bottom & Rounded & $8,5 \pm 1,33$ & $7,1 \pm 1,24$ & $1,08 \pm 0,053$ & $1,35 \pm 0,05$ & $1,65 \pm 0,07$ \\
\hline Poeciliidae & Poecilia gillii (Kner 1863) & 6 & Surface & Rounded & $4,6 \pm 1,63$ & $3,36 \pm 1,08$ & $0,94 \pm 0,47$ & $0,95 \pm 0,83$ & $8,28 \pm 0,45$ \\
\hline
\end{tabular}


that influence the speed of the burst swim (Table 2, Fig. 2 ), thus fish with an elongated body and truncated and convex tails, such as $P$. dovi and $A$. nigrofasciata, display a swim faster than those fish with rounded tails such as $P$. gilli or S. salvini.

TABLE 2

Results of Principal Components Analysis of corporal variable data from six freshwater fish species: correlation coefficients of Components 1 and 2 and the variables

\begin{tabular}{lcc}
\multicolumn{1}{c}{ Corporal variable } & PC 1 & PC 2 \\
Total length $(\mathrm{cm})$ & 0,606 & $-0,52128$ \\
Standard length $(\mathrm{cm})$ & 0,4931 & $-0,3363$ \\
Tail height $(\mathrm{cm})$ & 0,21107 & 0,32653 \\
Tail Area $\left(\mathrm{cm}^{2}\right)$ & 0,58415 & 0,686 \\
\hline
\end{tabular}

The Non-parametric Multidimensional Analysis (NMDS) test was grouped according to the speed, total length, tail area, body height and position on the water column (PWC) (Fig. 3). The ordination test differed in grouping for fishes from bottom and medium water column. The surface group overlaps with the rest of groups, being surface species the fastest.

\section{DISCUSSION}

This is the first study to describe the explosive swimming of six species of freshwater fish for Costa Rica. Previous studies have focused on migratory species of economic importance or marine species, which is why we have focused on smaller species that are less researched, with less knowledge of their ecology. Whilst this study analyzed a small portion of the species richness, the relationships between morphologic diversity among the dominant families has clear importance for freshwater ecosystems.

All the species used in this study have rounded, truncated and convex tails (Table 1). In the case of the species $A$. nigrofasciata, it presented the fastest explosive swim due to its body compressed laterally and truncated tail. Studies have shown that the tail of fish play an important role on the swimming process, as this body part under goes complex deformations independent of the body (curvature, area and angle) (Videler, 1993; Lauder, 2000; Lauder, Drucker, Nauen, \& Wilga, 2003). Other characteristics that must be highlighted are the ecological features, such as behaviour and feeding. For

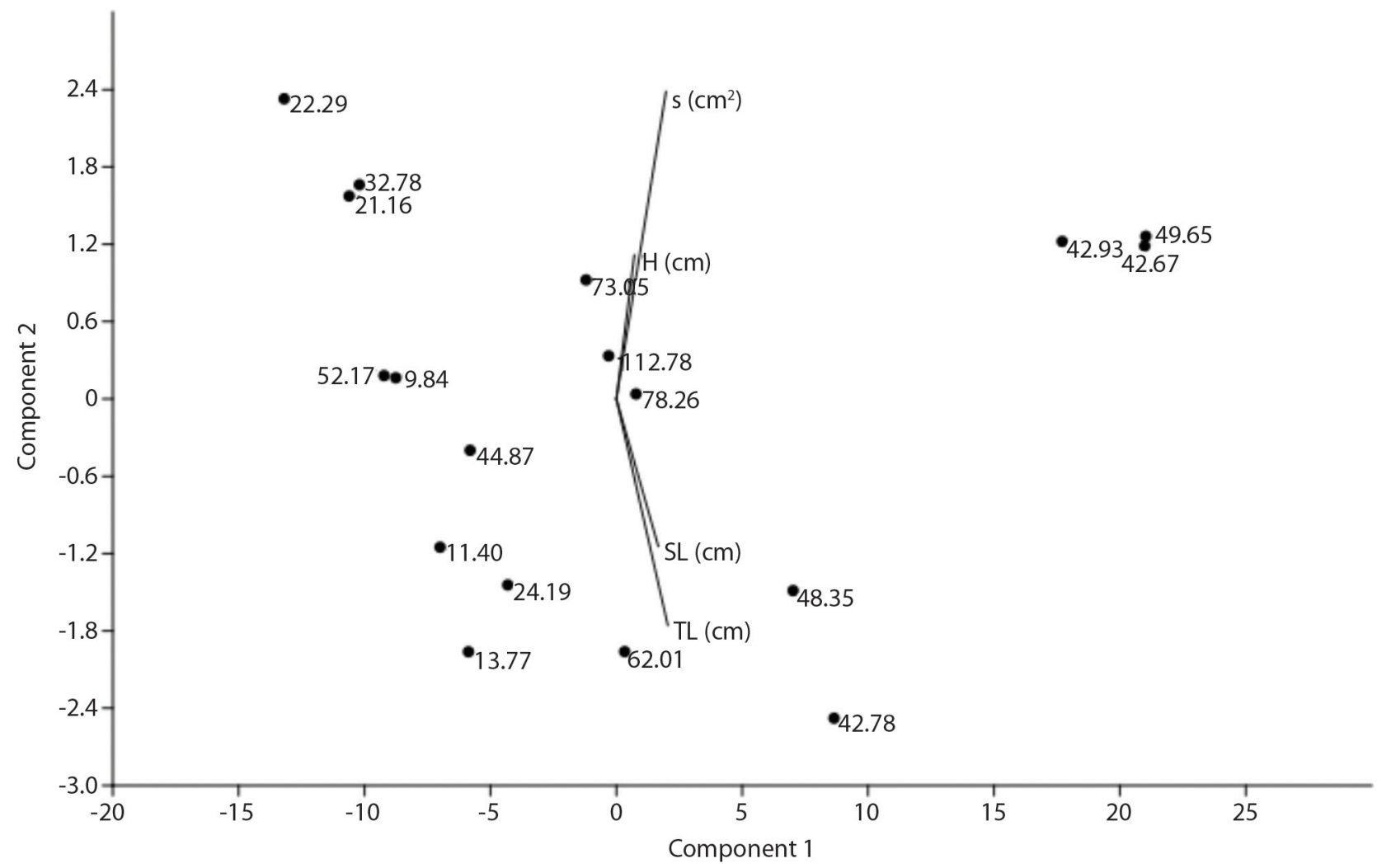

Fig. 2. Principal component analyses (PCA). Relationship between explosive swimming and the morphological characteristics of the fish. (explained variance: factor 1) $98,08 \%$; factor 2) 1,74\%. TL=Total length; $\mathrm{SL}=$ Standard length; $\mathrm{H}=$ Tail height; $\mathrm{s}=$ Tail Area. 


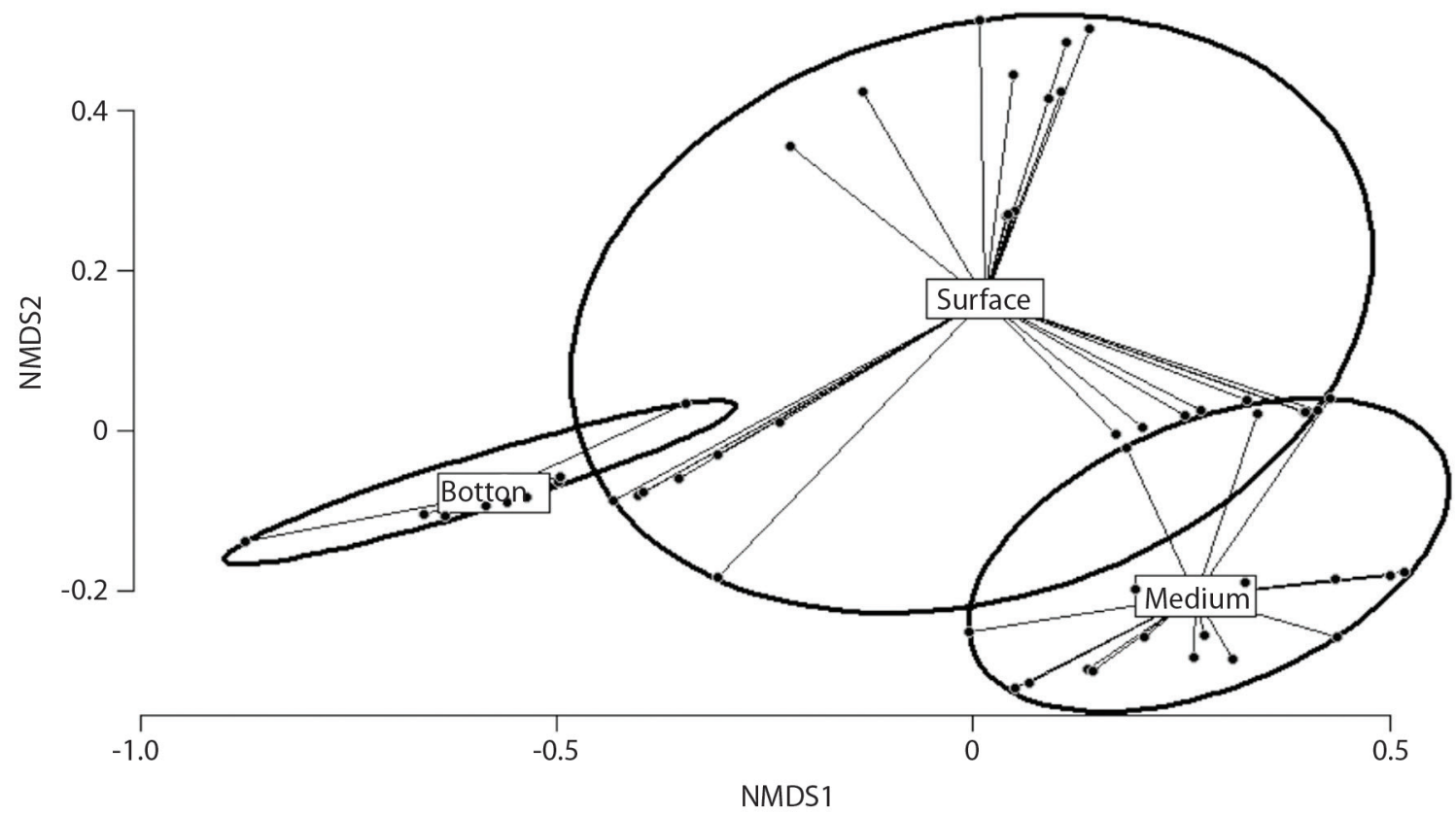

Fig. 3. Non-parametric Multidimensional Analysis (nMDS) shows the grouping according to the type of tail and speed of the fish sampled and the position in the water column. The dots refer to species and ellipses represent $95 \% \mathrm{Cl}$ around the centroid (Stress $=0,07)$.

example, A. nigrofasciata requires rapid movements to ram its prey (Ferry, Paig-Tran, \& Gibb, 2015), while S. salvini has a slower swim speed when scraping the bottom (Barbee, 2005).

Previous studies mention that species have morphological and physiological adaptations to live in different habitats offered by the river (Barbee, 2005; Pichler \& Schiemer, 2008; Kipanyula \& Maina, 2016). The characteristics of the riverine ecosystem affects mobility and locomotion of species, thus changes in the ecosystems will cascade through the systems and impact all the species (Lupandin, 2005; Katopodis, 2005; Mueller, Pander, \& Geist, 2011; Binning et al., 2013; Domenici et al., 2013; Afshan et al., 2014; Winemiller et al., 2016). Thus, under this premise, it is believed that S. salvini displays the slowest swim burst because it lives on the riverbed (where stones, trunks, branches, roots and other obstacles are found) so an explosive swim must be quick to escape predators, but at the same time allow it to manoeuvre to avoid obstacles.

The study suggests that morphological characters distinguishing the elongated body, truncated and convex tails display a swim faster than those fish with rounded tails (Table 2). The body type is a fundamental characteristic that determines the explosive swim (Wardle \& $\mathrm{He}$, 1988). Other important factors are body phenotypes and absence of predators (Langerhans, Layman, Shokrollahi, \& DeWitt, 2004; Langerhans \& Reznick, 2010) which will modify the explosive swim.

The study of fish assemblages is associated with patterns of variation within freshwater ecosystems (Mims \& Olden, 2012; Pease, Gonzalez-Diaz, Rodiles-Hernandez, $\&$ Winemiller, 2012). Our results suggest there are two well-portrayed assemblages regarding the position in the water column. The NMDS (Fig. 2) showed a difference between medium and bottom, while the surface species overlap with all the other groups. Based on the results, it is possible to verify that there is a similarity of ecomorphological forms among sampled species. Both lotic the morphological features as the ecological will determine differences in the explosive swimming speed.

Further research on the patterns of niche partitioning should be complemented with trophic ecology. Other important topic to be considered for future research is the study of how other physical variables modify this explosive swing (temperature, oxygen level). This will be particularly important since the country has a considerable hydroelectric dams development and such infrastructure generates a constraint for the passage of fish, changes in temperature and modification on the river flow (Arias \& Alvarado, 2013; McManamay et al., 2015; Farah, 2016; Winemiller et al., 2016). 
We concluded that the burst swim depends of Morphological and ecological characteristics. In this way, the species $A$. nigrofasciata obtained the fastest burst swim to the type of tail, size of the organism and the position in the water column that it usually inhabits.

\section{ACKNOWLEDGMENTS}

Authors want to thank Helena Molina from the Biology School of the Universidad de Costa Rica, Claire Tanner from University of Bath and to our peer reviewers all their comments and advice helped to improve substantially this manuscript. Additionally, to Juan Ulloa of the Universidad Nacional, his contribution and facilities helped carry this experiment. Finally, to the Postgraduate System of the Universidad de Costa Rica (SEP).

\section{REFERENCES}

Afshan, S., Ali, S., Ameen, U. S., Farid, M., Bharwana, S. A., Hannan, F., \& Ahmad, R. (2014). Effect of different heavy metal pollution on fish. Research Journal of Chemical and Environmental Sciences, 2(1), 74-79.

Altringham, J. D., \& Ellerby, D. J. (1999). Fish swimming: patterns in muscle function. Journal of Experimental Biology, 202(23), 3397-3403.

Arias, I. G., \& Alvarado, J. C. C. (2013). Planning and development of Costa Rica water resources: current status and perspectives. Tecnología en Marcha, 26(4), 52-63. DOI: 10.18845/tm.v26i4.1583

Barboza, J. P., \& Villalobos, G. U. (2018). Fish assemblages and their ecological traits along an elevational gradient in the Río Pacuare, Costa Rica. Revista de Biología Tropical, 66(1), S132-S152. DOI: 10.15517/rbt.v66i1.33269

Barbee, N. C. (2005). Grazing insects reduce algal biomass in a neotropical stream. Hydrobiologia, 532(1-3), 153-165. DOI: 10.1007/s10750-004-9527-z

Benavides, A. M. S., Barboza, J. P., Rodríguez, F. M., \& Gairaud, C. G. (2015). Sedimentological implications of the change in the coverage of mangrove forest in Boca Zacate, Térraba-Sierpe National Wetlands, Costa Rica. Revista de Biología Tropical, 63(3), 591-601. DOI: 10.15517/rbt. v63i3.16173

Binning, S. A., Roche, D. G., \& Layton, C. (2013). Ectoparasites increase swimming costs in a coral reef fish. Biology Letters, 9(1), 20120927. DOI: 10.1098/rsbl.2012.0927

Blake, R. W. (1983). Median and paired fin propulsion. Fish Biomechanics, 1983, 214-247.

Blake, R. W. (2004). Fish functional design and swimming performance. Journal of fish biology, 65(5), 1193-1222. DOI: 10.1111/j.0022-1112.2004.00568.x
Bussing, W. A. (2002). Peces de las aguas continentales de Costa Rica. San José, Costa Rica: Editorial de la Universidad de Costa Rica.

Campos, L. D. A. (2017). Do hydroelectric projects affect aquatic plants? The case of Marathrum foeniculaceum (Podostemaceae) in two rivers, Southeastern Costa Rica. UNED Research Journal, 9(2), 305-312.

Chapman, L., Kramer, D. \& Chapman, C. (1991). Population dynamics of the fish Poecilia gillii (Poecillidae) in pools of an intermittent tropical stream. Journal of Animals Ecology, 60, 441-453. DOI: 10.2307/5289

Djumanto, D., Ustadi, U., Rustadi, R., \& Triyatmo, B. (2018). Utilization of Wastewater from Vannamei Shrimp Pond for Rearing Milkfish in Keburuhan Coast Purworejo Sub-District. Aquacultura Indonesiana, 19(1), 38-46. DOI: 10.21534/ai.v19i1.48

Domenici, P., Herbert, N. A., Lefrançois, C., Steffensen, J. F., \& McKenzie, D. J. (2013). The effect of hypoxia on fish swimming performance and behaviour. In Swimming physiology of fish. Berlin, Germany: Springer. DOI: 10.1007/978-3-642-31049-2_6

Eschmeyer, W. N. (Ed). (2018). Catalog of Fishes. California Academy of Sciences. Retrieved from http://research. calacademy.org/research/ichthyology/catalog/fishcatmain.asp. 24/3/2014

Farah, A. P. (2016). Fragmentación del hábitat por represas hidroeléctricas para la ictiofauna dulceacuícola en Costa Rica (tesis de licenciatura). San José, Costa Rica: Universidad de Costa Rica.

Faria, A. M., \& Gonçalves, E. J. (2010). Ontogeny of swimming behaviour of two temperate clingfishes, Lepadogaster and L. purpurea (Gobiesocidae). Marine Ecology Progress Series, 414, 237-248. DOI: 10.3354/meps08692

Fausch, K. D., Torgersen, C. E., Baxter, C. V., \& Li, H. W. (2002). Landscapes to riverscapes: bridging the gap between research and conservation of stream fishes. Biosciences, 52(6), 483-498. DOI: 10.1641/0006-3568(2002)052[0483:LTRBTG]2.0.CO;2

Ferry, L. A., Paig-Tran, E. M., \& Gibb, A. C. (2015). Suction, ram, and biting: deviations and limitations to the capture of aquatic prey. Integrative and Comparative Biology, 55(1), 97-109. DOI: 10.1093/icb/icv028

Flammang, B. E., Tangorra, J. L., Mignano, A. P., \& Lauder, G. V. (2017). Building a Fish: The Biology and Engineering Behind a Bioinspired Autonomous Underwater Vehicle. Marine Technology Society Journal, 51(5), 15-22. DOI: 10.4031/MTSJ.51.5.1

Gibson, R. J., Haedrich, R. L., \& Wernerheim, C. M. (2005). Loss of fish habitat as a consequence of inappropriately constructed stream crossings. Fisheries, 30(1), 10-17. DOI: 10.1577/1548-8446(2005)30[10:LOFHAA]2.0.CO;2

Holden, M. J., \& Raitt, D. F. S. (1974). Manual of fisheries science. Part 2-Methods of resource investigation and their application. Denmark: FAO/DANIDA. 
Johansen, J. L., \& Jones, G. P. (2011). Increasing ocean temperature reduces the metabolic performance and swimming ability of coral reef damselfishes. Global Change Biology, 17(9), 2971-2979. DOI: 10.1111/j.1365-2486.2011.02436.x

Katopodis, C. (2005). Developing a toolkit for fish passage, ecological flow management and fish habitat works. Journal of Hydraulic Research, 43(5), 451-467. DOI: 10.1080/00221680509500144

Kipanyula, M. J., Maina, K. W., \& Maulilio Kipanyula, C. J. (2016). Morphological and adaptational changes associated with fish migration from fresh to marine water bodies. International Journal of Fisheries and Aquatic Studies, 4, 125-129.

Langerhans, R. B., Layman, C. A., Shokrollahi, A. M., \& DeWitt, T. J. (2004). Predator-driven phenotypic diversification in Gambusia affinis. Evolution, 58(10), 2305-2318. DOI: 10.1111/j.0014-3820.2004.tb01605.x

Langerhans, R. B., \& Reznick, D. N. (2010). Ecology and evolution of swimming performance in fishes: predicting evolution with biomechanics. Fish Locomotion: an eco-ethological perspective, 220, 248. DOI: 10.1201/b10190-8

Lauder, G. V. (2000). Function of the caudal fin during locomotion in fishes: kinematics, flow visualization, and evolutionary patterns. American Zoologist, 40(1), 101-122. DOI: $10.1093 / \mathrm{icb} / 40.1 .101$

Lauder, G. V., Drucker, E. G., Nauen, J. C., \& Wilga, C. D. (2003). Experimental hydrodynamics and evolution: caudal fin locomotion in fishes. In V. L. Bels, J. P. Gasc \& A. Casinos (Eds), Vertebrate Biomechanics and Evolution (pp. 117135). Oxford, England: BIOS Scientific Publishers Ltd.

Liao, J. C. (2007). A review of fish swimming mechanics and behaviour in altered flows. Philosophical Transactions of the Royal Society B: Biological Sciences, 362(1487), 1973-1993.

Lupandin, A. I. (2005). Effect of flow turbulence on swimming speed of fish. Biology Bulletin, 32(5), 461-466. DOI: 10.1007/s10525-005-0125-z

McManamay, R. A., Peoples, B. K., Orth, D. J., Dolloff, C. A., \& Matthews, D. C. (2015). Isolating causal pathways between flow and fish in the regulated river hierarchy. Canadian journal of fisheries and aquatic sciences, 72(11), 1731-1748.

Maddock, L., Bone, Q., \& Rayner, J. M. (Eds.). (1994). The Mechanics and Physiology of Animal Swimming. Cambridge, U.K.: Cambridge University Press. DOI: 10.1017/CBO9780511983641

Marras, S., Killen, S. S., Lindström, J., McKenzie, D. J., Steffensen, J. F., \& Domenici, P. (2015). Fish swimming in schools save energy regardless of their spatial position. Behavioral Ecology and Sociobiology, 69(2), 219-226. DOI: 10.1007/ s00265-014-1834-4
Mims, M. C., \& Olden, J. D. (2012). Life history theory predicts fish assemblage response to hydrologic regimes. Ecology, 93(1), 35-45. DOI: 10.1890/11-0370.1

Mueller, M., Pander, J., \& Geist, J. (2011). The effects of weirs on structural stream habitat and biological communities. Journal of Applied Ecology, 48(6), 1450-1461. DOI: 10.1111/j.1365-2664.2011.02035.x

Nelson, J. A., \& Claireaux, G. (2005). Sprint swimming performance of juvenile European sea bass. Transactions of the American Fisheries Society, 134(5), 1274-1284.

Nowroozi, B. N., \& Brainerd, E. L. (2014). Importance of mechanics and kinematics in determining the stiffness contribution of the vertebral column during body-caudal-fin swimming in fishes. Zoology, 117(1), 28-35. DOI: 10.1016/j.zool.2013.10.003

Pease, A. A., Gonzalez-Diaz, A. A., Rodiles-Hernandez, R., \& Winemiller, K. O. (2012). Functional diversity and traitenvironment relationships of stream fish assemblages in a large tropical catchment. Freshwater Biology, 57(5), 1060-1075. DOI: 10.1111/j.1365-2427.2012.02768.x

Perkin, J. S., Gido, K. B., Cooper, A. R., Turner, T. F., Osborne, M. J., Johnson, E. R., \& Mayes, K. B. (2015). Fragmentation and dewatering transform Great Plains stream fish communities. Ecological Monographs, 85(1), 73-92. DOI: 10.1890/14-0121.1

Picado, J. N., Parallada, M. S., Mora, A. M., \& Sánchez, A. F. (2017). Selección de hábitat de Lontra longicaudis (Carnivora, Mustelidae) bajo la influencia de la represa hidroeléctrica del río Peñas Blancas y sus tributarios, Alajuela, Costa Rica. Uniciencia, 31(1), 73-84. DOI: 10.15359/ru.31-1.8

Pichler, C., \& Schiemer, F. (2008). Ecology of fishes of Quebrada Negra, Costa Rica, a first order neotropical lowland stream. Ecología de los peces de Quebrada Negra, Costa Rica, río neotropical de primer orden de tierras bajas. Stapfia, 88, 495-505.

Plaut, I. (2001). Critical swimming speed: its ecological relevance. Comparative Biochemistry and Physiology Part A: Molecular \& Integrative Physiology, 131(1), 41-50. DOI: 10.1016/S1095-6433(01)00462-7

Robolledo, M., Landaeta, M. \& Muñoz, G. (2014). Efecto del endoparásito Prosorhynchoides sp. (Trematoda: Bucephalidae) en la capacidad de nado sostenido del baunco Girella laevifrons (Osteichthyes: Kyphosidae). Revista de Biología Marina y Oceanografía, 49(3), 625-630.

Reidy, S. P., Kerr, S. R., \& Nelson, J. A. (2000). Aerobic and anaerobic swimming performance of individual Atlantic cod. Journal of Experimental Biology, 203(2), 347-357.

Sfakiotakis, M., Lane, D. M., \& Davies, J. C. (1999). Review of fish swimming modes for aquatic locomotion. IEEE Journal of Oceanic Engineering, 24(2), 237-252. DOI: $10.1109 / 48.757275$

Shang, L., Wang, S., Tan, M., \& Cheng, L. (2012). Swimming locomotion modeling for biomimetic underwater vehicle 
with two undulating long-fins. Robotica, 30(6), 913-923. DOI: $10.1017 /$ S0263574711001159

Sibaja, A. A., Bussing, W., Garita-Alvarado, C., \& López, M. (2013). Annotated checklist of the freshwater fishes of continental and insular Costa Rica: additions and nomenclatural revisions. Check List, 9, 987. DOI: 10.15560/9.5.987

Tabash, F. B. \& Guadamuz, S. (2000). A management plan for the sport fishery of Parachromis dovii (Pisces: Cichlidae) (Gunther 1864) in Hule lake, Costa Rica. Revista de Biologia Tropical, 48(2-3), 473-485.

Trujillo-Jiménez, P. (1998). Trophic spectrum of the cichlids Cichlasoma (Parapetenia) istlanum and Cichlasoma (Arconcentrus) nigrofasciatum in the Amacuzac River, Morelos, Mexico. Journal of Freshwater Ecology, 13(4), 465-473. DOI: 10.1080/02705060.1998.9663643

Videler, J. J. (1993). Fish Swimming. London, U.K.: Chapman \& Hall. DOI: 10.1007/978-94-011-1580-3

Wardle, C., \& He, P. (1988). Burst swimming speeds of mackerel, Scomber scombrus. Journal of Fish Biolology, 32, 471478. DOI: 10.1111/j.1095-8649.1988.tb05382.x
Weihs, D. (1973). Energetic Advantages of Burst Swimming of Fish. Journal of Theoretical Biology, 48(1), 215-229. DOI: 10.1016/0022-5193(74)90192-1

Winemiller, K. O., McIntyre, P. B., Castello, L., Fluet-Chouinard, E., Giarrizzo, T., Nam, S., Baird, G., Darwall, W., Lujan, N. K., Harrison, I., Stiassny, M. L. J., Silvano, R. A. M., Fitzgerald, D. B., Pelicice, F. M., Agostinho, A. A., Gomes, L. C., Albert, J. S., Baran, E., Petrere Jr., M., Zarfl, C., Mulligan, M., Sullivan, J. P., Arantes, C. C., Sousa, L. M., Koning, A. A., Hoeinghaus, D. J., Sabaj, M., Lundberg, J. G., Armbruster, J., Thieme, M. L., Petry, P., Zuanon, J., Torrente, G. V., Snoeks, J., Rainboth, C. W., Pavanelli, C. S., Akama, A., van Soesbergen, A., \& Sáenz, L. (2016). Balancing hydropower and biodiversity in the Amazon, Congo, and Mekong. Science, 351(6269), 128-129. DOI: 10.1126/ science.aac7082

Wisenden, B. D. (1994). Factors affecting reproductive success in free-ranging convict cichlids (Cichlasoma nigrofasciatum). Canadian Journal of Zoology, 72(12), 2177-2185. DOI: 10.1139/z94-291 